\title{
Expression of Epidermal Growth Factor Receptor and Transforming Growth Factor Alpha in Cancer Bladder: Schistosomal and Non-Schistosomal
}

\author{
Afkar A. Badawy ${ }^{a} \quad$ Ali El-Hindawi ${ }^{\mathrm{b}} \quad$ Olfat Hammam $^{\mathrm{a}} \quad$ Mona Moussa $^{\mathrm{a}}$ \\ Noha S. Helal ${ }^{\mathrm{a}} \quad$ Amira Kamel $^{\mathrm{a}}$ \\ ${ }^{a}$ Department of Pathology, Theodor Bilharz Research Institute; ${ }^{\mathrm{b}}$ Department of Pathology, Faculty of Medicine, \\ Cairo University, Giza, Egypt
}

\section{Key Words}

Bladder cancer • Epidermal growth factor receptor • Immunohistochemistry • Schistosomiasis •

Transforming growth factor- $a$

\begin{abstract}
Introduction: Overexpression of epidermal growth factor receptor (EGFR) has been described in several solid tumors including bladder cancer. Transforming growth factor alpha (TGFa) is frequently deregulated in neoplastic cells and plays a role in the development of bladder cancer. TGFa-EGFR ligand-receptor combination constitutes an important event in multistep tumorigenesis. Methods: This study was done on 30 bladder biopsies from patients with urothelial carcinoma, 15 with squamous cell carcinoma, 10 with cystitis and 5 normal control bladder specimens. All were immuohistochemically stained with EGFR and TGFa antibodies. Results: EGFR and TGFa were over-expressed in higher grades and late stages of bladder cancer. Moreover, they show higher expression in squamous cell carcinoma compared to urothelial carcinoma and in schistosomal associated lesions than in non-schistosomal associated lesions. Conclusion: EGFR and TGFa could be used as prognostic predictors in early stage and grade of bladder cancer cases, especially those with schistosomal association. In addition they can help in selecting patients who can get benefit from anti-EGFR molecular targeted therapy.

Copyright ๑ 2015 S. Karger AG, Basel
\end{abstract}

KARGER

Fax +4161306 1234

E-Mail karger@karger.ch

www.karger.com
(C) 2015 S. Karger AG, Basel

1015-9770/15/0094-0192\$38.00/0

Accessible online at:

www.karger.com/cur

\section{Introduction}

The bladder is a common site for cancer development in the urinary tract [1]. Urinary bladder cancer ranks ninth in worldwide cancer incidence with approximately 356,000 new cases each year [2] as it is the fourth most common in males, and the ninth most common in females [3]. Furthermore, approximately 145,000 patients die from this disease worldwide per year [2].

The term bladder cancer is used to describe collectively tumors of urinary bladder of urothelial origin which exhibit diverse biological characteristics. In developed countries, urothelial carcinoma (UC) accounts for $95 \%$ of bladder cancer cases, and occurs mainly after the age of 60 years [4]. Elsewhere in areas endemic for chronic urinary Schistosomiasis, squamous cell carcinoma (SCC) is the most common type, occurs at younger ages, and usually associated with squamous metaplasia [5].

In Egypt, urinary bladder cancer is the foremost oncological problem with many pathogenic factors most commonly schistosomal infestation [1]. It accounts for about $30 \%$ of all cancers, $40 \%$ of male cancers and $14 \%$ of female cancers [6]. SCC is linked with chronic infection with Schistosoma haematobium [1, 7].

Epidermal growth factor receptor (EGFR) is a member of the tyrosine kinase receptor family, a group of receptors which are all encoded by the c-erbB oncogene. It 
Table 1. Grades and stages of studied malignant bladder lesions

\begin{tabular}{|c|c|c|c|}
\hline Category & $\begin{array}{l}\text { UC } \\
\mathrm{n}(\%)\end{array}$ & $\begin{array}{l}\text { SCC } \\
\mathrm{n}(\%)\end{array}$ & $\begin{array}{l}\text { Total } \\
\mathrm{n}(\%)\end{array}$ \\
\hline \multicolumn{4}{|l|}{ Grade } \\
\hline I & $11(36.7)$ & $4(26.7)$ & $15(33.3)$ \\
\hline II & $12(40)$ & $6(40)$ & $18(40)$ \\
\hline III & $7(23.3)$ & $5(33.3)$ & $12(26.7)$ \\
\hline \multicolumn{4}{|c|}{ Pathological stage } \\
\hline $\mathrm{T} 1$ & $15(50)$ & $5(33.3)$ & $20(44.4)$ \\
\hline $\mathrm{T} 2$ & $11(36.7)$ & $5(33.3)$ & $16(35.6)$ \\
\hline T3 & $4(13.3)$ & $5(33.3)$ & $9(20)$ \\
\hline Total & 30 & 15 & 45 \\
\hline
\end{tabular}

$\mathrm{UC}=$ Urothelial carcinoma; $\mathrm{SCC}=$ squamous cell carcinoma.

Table 2. Effect of Schistosomal association on tumor grade and stage

\begin{tabular}{llll}
\hline Category & $\begin{array}{l}\text { Non-schistosomal } \\
\mathrm{n}(\%)\end{array}$ & $\begin{array}{l}\text { Schistosomal } \\
\mathrm{n}(\%)\end{array}$ & $\begin{array}{l}\text { Total } \\
\mathrm{n}(\%)\end{array}$ \\
\hline Grade & & & \\
$\quad$ I & $8(44.4)$ & $7(26)$ & $15(33.3)$ \\
$\quad$ II+III & $10(55.6)$ & $20(74)$ & $30(66.7)$ \\
Pathological stage & & & \\
$\quad$ Superficial (T1) & $11(61.1)$ & $9(33.3)$ & $20(44.4)$ \\
$\quad$ Invasive (T2+T3) & $7(38.9)$ & $18(66.7)$ & $25(55.6)$ \\
Total & 18 & 27 & 45 \\
\hline
\end{tabular}

has been reported to be involved in the pathological processes of several cancers through interaction with other ligands like transforming growth factor alpha (TGF $\alpha$ ) [8]. EGFR plays critical roles in cell growth, differentiation, motility, and survival [9]. It was reported to be overexpressed in a variety of solid malignancies including UC [10]. Several investigators have suggested that expression of EGFR could be utilized for molecular targeted therapy in urinary bladder cancer [11-13].

$\mathrm{TGF} \alpha$ is a mitogenic polypeptide that has a wide range of biological activities including self-renewing epithelia; it acts as a paracrine growth factor through its interaction with EGFR [14]. The ability of TGF $\alpha$ to contribute to transformation and oncogenesis occurs through the activation of EGFR [15]. Overexpression of TGF $\alpha$ appears to be an event in bladder cancer that occurs more frequently in schistosomal bladder cancer and SCC, and may play an important role in their development. These observations may provide insight into treatment guided by molecular changes [16].

The present study was conducted to evaluate immunohistochemical expression of EGFR and TGF $\alpha$ in urothelial cells of chronic cystitis and urinary bladder cancer with or without schistosomal affection.

\section{Materials and Methods}

\section{Specimens}

A total of 55 archival urinary bladder blocks from Pathology Department of Theodor Bilharz Research Institute were included in this study; obtained either as transurethral resections or radical cystectomy specimens. They consisted of 10 cases of cystitis, 30 UC and 15 SCC. They belong to 47 males and 8 females (mean age $55.41 \pm 12.73$ years, range $27-74$ years). In addition, 5 normal bladder specimens were obtained from patients subjected to prostatectomy after taking their consent, and served as controls (mean age $66.00 \pm 5.38$ years, range $57-71$ years)

\section{Histopathological Study}

Five micron serial sections were stained with hematoxylin \& eosin. The 60 biopsies were categorized into the following groups: Group 1: Control $(\mathrm{n}=5)$; Group 2: Cystitis/schistosomal $(\mathrm{n}=5)$ and non-schistosomal $(\mathrm{n}=5)$; Group 3: $\mathrm{UC} /$ schistosomal $(\mathrm{n}=17)$ and non-schistosomal $(\mathrm{n}=13)$; Group 4: SCC/schistosomal $(\mathrm{n}=$ 10) and non-schistosomal $(\mathrm{n}=5)$.

\section{Histological Grading}

Urinary bladder tumors were histologically divided into 3 grades (I-III).

\section{Pathological staging}

Staging of bladder tumors followed WHO classification [17].

Tumors of grade I are considered of low grade, while those in grades II and III are of high grade. Tumors of pathological stage $\mathrm{T} 1$ are considered superficial and that $>\mathrm{T} 1$ are muscle invasive.

Schistosomal infection was diagnosed upon presence of Schistosoma ova in tissue samples.

\section{Immunohistochemical technique}

Formalin-fixed paraffin embedded sections ( $5 \mu \mathrm{m}$ in thickness) were cut. Sections were incubated in oven at $60^{\circ} \mathrm{C}$ overnight, deparaffinization and rehydration were done. Endogenous peroxidase was blocked with methanol containing 3\% hydrogen peroxide. Antigen retrieval was performed by microwaving the sections in citrate buffer, $\mathrm{pH}$ 6.0. Sections were incubated overnight at $4{ }^{\circ} \mathrm{C}$ in humid chamber with the primary antibodies: EGFR monoclonal antibody (Dako, Code no. Ab1006, Glostrup, Denmark) and TGF $\alpha$ polyclonal antibody (Abcam, Ab 9578, Cambridge, Massachusette, USA), at an optimal dilution of 1:50 for both, with application of ultravision detection system HRP Polymer. The antigen was localized by the addition of DAB (3, 3' Diaminobenzidine) substrate chromogen solution. Finally, slides were counterstained with hematoxylin, dehydrated in alcohol and mounted.

For each setting, negative controls were carried out in which phosphate buffered saline was used instead of the primary antibody. Skin biopsies were used as positive controls for both antibodies.

\section{Interpretation of Immunostaining}

All immunostained slides were assessed and scored. The sections were examined by using light microscope (Zeiss, Germany). For EGFR, immunopositivity was indicated by brownish cytoplasmic or membranous staining in the urothelial cells while TGF alpha positivity was detected as brownish cytoplasmic staining in 
Table 3. EGFR expression in studied groups

\begin{tabular}{|c|c|c|c|c|c|}
\hline \multirow[t]{2}{*}{ Studied groups (n) } & \multirow{2}{*}{$\begin{array}{l}\text { Positive cases } \\
\mathrm{n}(\%)\end{array}$} & \multicolumn{4}{|c|}{ Extent of EGFR immunoreactivity } \\
\hline & & $\%$ of positive cells (Mean \pm SD) & Score $1+, \mathrm{n}(\%)$ & Score $2+, \mathrm{n}(\%)$ & Score $3+, \mathrm{n}(\%)$ \\
\hline Control (5) & 0 & 0 & - & - & - \\
\hline Chronic cystitis (10) & $1(10)$ & $2.00 \pm 6.32$ & $1(100)$ & 0 & 0 \\
\hline Schistosomal cystitis (5) & $1(20)$ & $4.00 \pm 8.94$ & $1(100)$ & - & - \\
\hline Carcinomas (45) & $39(86.7) *$ & $43.51 \pm 23.54 *$ & 0 & $21(53.8)$ & $18(46.2)$ \\
\hline Non-Schistosomal carcinomas (18) & $15(83.3)$ & $39.44 \pm 24.54$ & 0 & $11(73.3)$ & $4(26.7)$ \\
\hline
\end{tabular}

EGFR $=$ Epidermal growth factor receptor; $*$ Significant difference compared to control and chronic cystitis $(\mathrm{p}<0.01)$.

Table 4. EGFR expression in malignant lesions

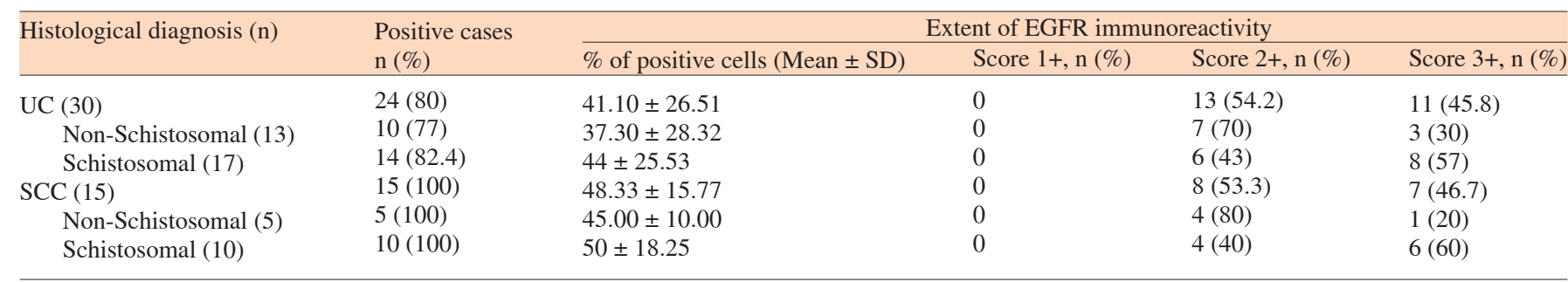

$\mathrm{EGFR}=$ Epidermal growth factor receptor; $\mathrm{UC}=$ urothelial carcinoma; $\mathrm{SCC}=$ squamous cell carcinoma.

urothelial cells. The percentage of positive cells was evaluated in 10 microscopic fields at power $\times 400$ and the mean value was obtained.

The percentage of stained cells in each section was estimated on a scale of $0-3$ (extent of expression), 0 (no positive cells), 1+ (positivity in $1-20 \%$ of cells), $2+$ (positivity in $21-50 \%$ of cells), and $3+$ (positivity in $>51 \%$ of cells). Immunostaining intensity of EGFR and TGF $\alpha$ were scored into mild, moderate and marked.

\section{Statistical Analysis}

SPSS for Windows, version 20 was used for statistical analysis (IBM Corporation, Armonk, New York, USA). Means of different groups were compared using one-way ANOVA. The correlation between EGFR and TGF $\alpha$ scores of immunoreactivity and histopathological stage, grade and schistosomal association was assessed by Spearman correlation coefficient. A p value $<0.05$ was considered significant.

\section{Results}

\section{Histopathology}

Among studied urothelial tumors (Group 3), UC was diagnosed in 30/45 (66.7\%) and SCC in 15/45 (33.3\%). Urothelial tumors were found to be 15 (33.3\%), 18
(40\%) and $12(26.7 \%)$ in grades I, II, and III respectively. Twenty (44.4\%), $16(35.6 \%)$ and $9(20 \%)$ were in stage $\mathrm{T} 1, \mathrm{~T} 2$, and $\mathrm{T} 3$ respectively (table 1 ). Schistosomiasis was diagnosed in $32 / 55(58.2 \%)$ of all studied lesions. It was diagnosed in $50 \%$ of chronic cystitis cases and in $60 \%$ of malignant cases $(56.6 \%$ of UC cases and $66.6 \%$ of SCC cases). In Schistosomal associated tumors, 20/27 $(74.1 \%)$ were muscle invasive (T2+T3), and 18/27 $(66.7 \%)$ were of high grade (grade II or III) versus $55.6 \%$ and $38.9 \%$ of non-Schistosomal associated tumors (table 2).

\section{EGFR Immunoexpression}

All control and chronic non schistosomal cystitis cases were negative for EGFR staining. Positivity of EGFR was expressed in urothelial cells as brownish cytoplasmic and/ or membranous staining. Only one case of chronic schistosomal cystitis (1/5) was positive for EGFR with weak expression (score 1+) showing mild staining intensity (table 3, Histogram 1 and fig. 1A).

Malignant cases positive for EGFR immunostaining were 39 cases out of 45 cases $(86.7 \%$ ), with moderate intensity in $69.3 \%$ of them. The extent of EGFR staining 


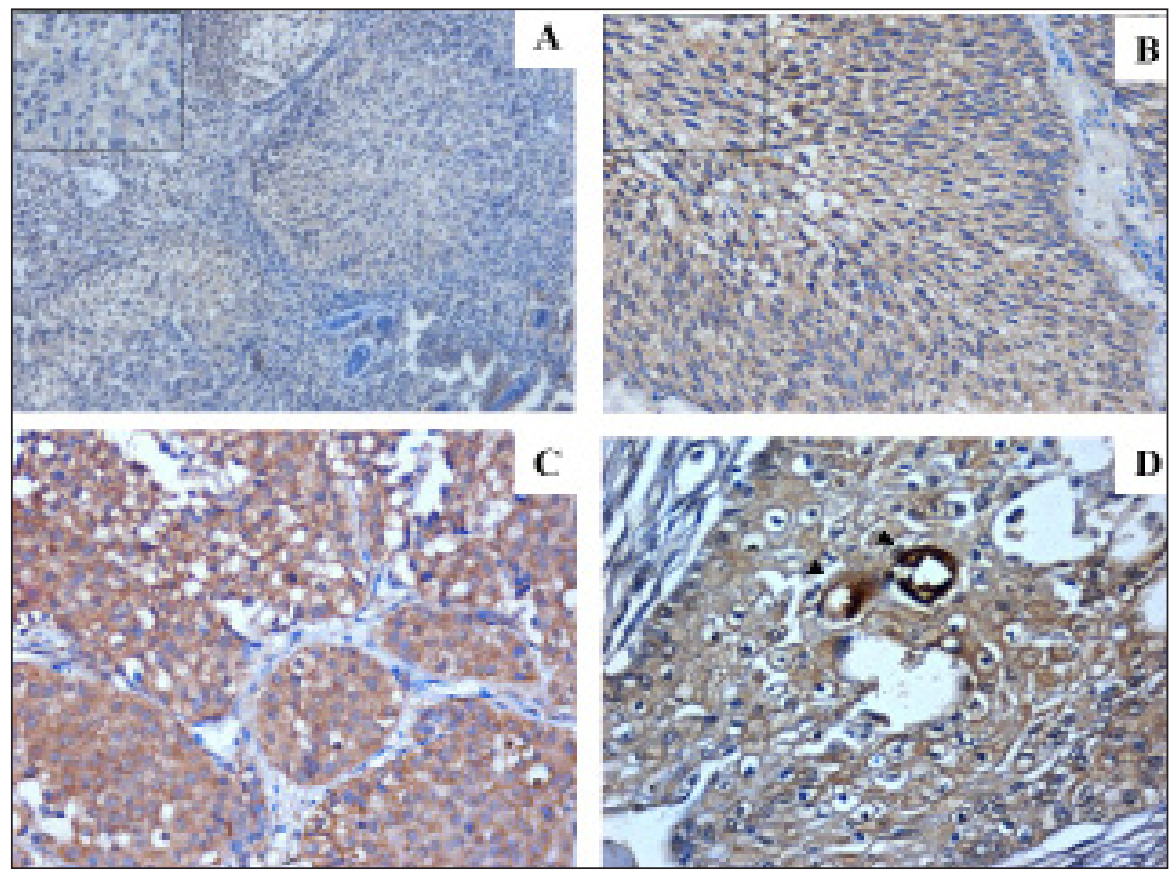

Fig. 1. Immunohistochemistry for EGFR in urinary bladder sections expressed as brown cytoplasmic and membranous staining of urothelial cells (A) Schistosomal cystitis (score $1+, \times 200$ ), (B) TCC Grade I (score $2+, \times 400$ ), (C) TCC Grade II (score $3+, \times 400)$, (D) SCC with schistosomiasis (arrowed) Grade II (score $3+, \times 400$ ). EGFR $=$ epidermal growth factor receptor; $\mathrm{TCC}=$ transitional cell carcinoma; $\mathrm{SCC}=$ squamous cell carcinoma.

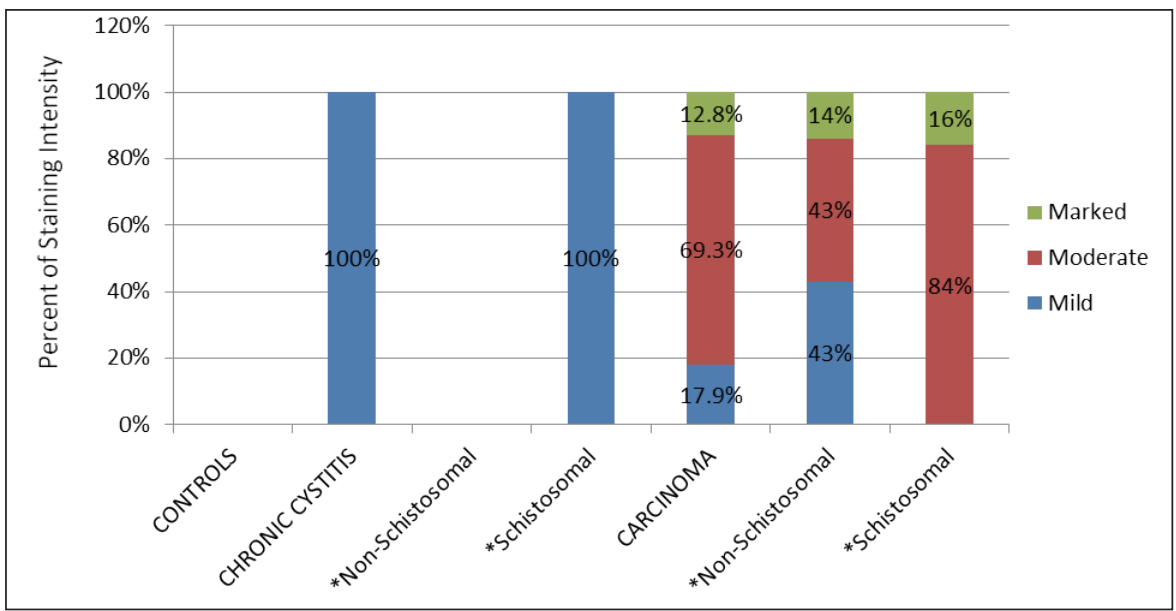

Histogram. 1. Intensity of EGFR expression in studied groups

(mean\% of positive cells) rose significantly in malignant cases versus cases of chronic cystitis $(\mathrm{p}<0.01)$ (table3, histogram 1). All cases of SCC were positive for EGFR versus $80 \%$ of UC cases without significant difference in its extent of expression or staining intensity between both tumor types (table 4, fig. 1B-D). 

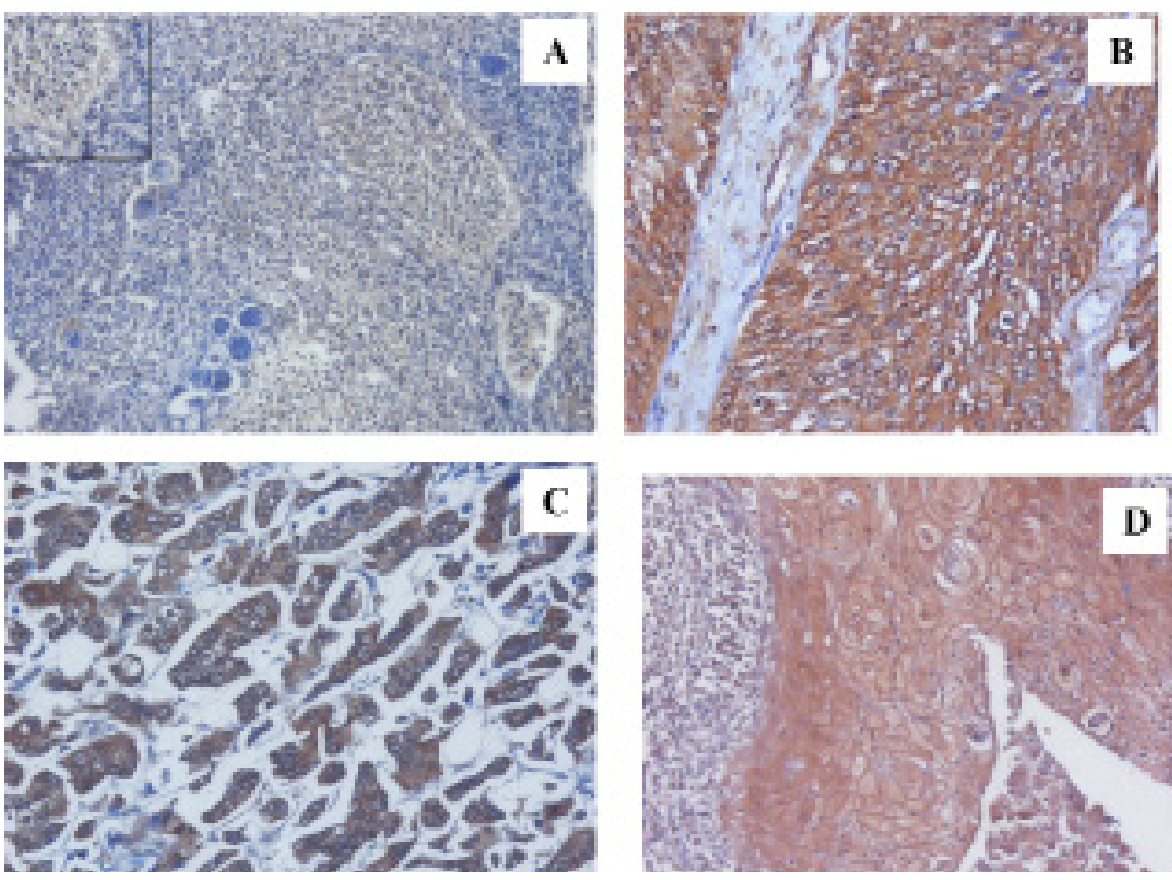

Fig. 2. Immunohistochemistry for $\mathrm{TGF} \alpha$ in urinary bladder sections expressed as brown cytoplasmic staining of urothelial cells, (A) Schistosomal cystitis (score 1+, $\times 200$ ), (B) Papillary TCC Grade II (score 3+, × 400), (C) TCC Grade III (score 3+, × 400), (D) SCC Grade II (score $3+, \times 200)$. TGF $=$ transforming growth factor alpha; TCC $=$ transitional cell carcinoma; $\mathrm{SCC}=$ squamous cell carcinoma.

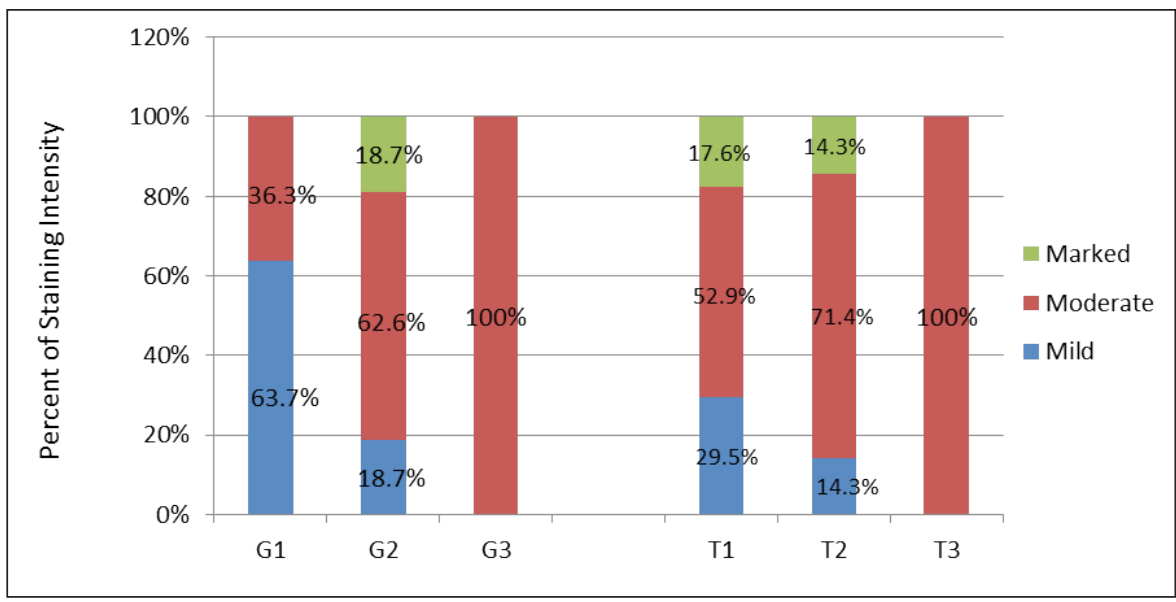

Histogram. 2. Intensity of EGFR in different grades and stages of positive malignant cases. $\mathrm{G}=$ Grade; $\mathrm{T}=$ Stage

Schistosomal association with bladder cancer increased extent of EGFR expression (score $3+$ ) as well as its staining intensity compared to non Schistosomal cancer cases in both cancer types (table 3, 4 and histogram $1)$.
As regards the studied grades and stages of bladder cancer; EGFR positivity, extent of expression as well as moderate staining intensity were found to be increased in grade 3 and stage 3 than in lower ones (table 5, histogram 2 and fig.1B-D). 
Table 5. EGFR expression in malignant grades and stages

\begin{tabular}{|c|c|c|c|c|c|}
\hline Histological diagnosis (n) & $\begin{array}{l}\text { Positive cases } \\
\mathrm{n}(\%)\end{array}$ & \multicolumn{4}{|c|}{ Extent of EGFR immunoreactivity } \\
\hline Grades & & & 0 & & \\
\hline Grade I (15) & $12(80)$ & $43.00 \pm 28.52$ & 0 & $6(50)$ & $6(50)$ \\
\hline Grade III (12) & $11(91.7)$ & $50.66 \pm 25.11$ & 0 & $3(27.3)$ & $8(72.7)$ \\
\hline Stages & & & 0 & & \\
\hline Stage $1(20)$ & $17(85)$ & $42.25 \pm 24.52$ & 0 & $11(64.7)$ & $6(35.3)$ \\
\hline
\end{tabular}

$\mathrm{EGFR}=$ Epidermal growth factor receptor.

Table 6. TGF- $\alpha$ expression in studied groups

\begin{tabular}{|c|c|c|c|c|c|}
\hline \multirow[t]{2}{*}{ Histological diagnosis (n) } & \multirow{2}{*}{$\begin{array}{l}\text { Positive cases } \\
\mathrm{n}(\%)\end{array}$} & \multicolumn{4}{|c|}{ Extent of TGF- $\alpha$ immunoreactivity } \\
\hline & & $\%$ of positive cells (Mean \pm SD) & Score $1+, \mathrm{n}(\%)$ & Score $2+, \mathrm{n}(\%)$ & Score $3+, \mathrm{n}(\%)$ \\
\hline Control (5) & $2(40)$ & $5.00 \pm 7.07$ & $2(100)$ & 0 & 0 \\
\hline Chronic cystitis (10) & $7(70)$ & $15.20 \pm 11.32 *$ & $6(85.7)$ & $1(14.3)$ & 0 \\
\hline Schistosomal cystitis (5) & $4(80)$ & $20.00 \pm 11.72$ & $3(75)$ & $1(25)$ & 0 \\
\hline Carcinomas (45) & $41(91.2)^{*}$ & $51.04 \pm 24.20^{*, * *}$ & $3(7.3)$ & $14(34.2)$ & $24(58.5)$ \\
\hline Non-Schistosomal carcinomas (18) & $15(83.3)$ & $45.00 \pm 25.72$ & $2(13.3)$ & $6(40)$ & $7(46.7)$ \\
\hline
\end{tabular}

TGF- $\alpha=$ Transforming growth factor alpha; *Significant difference compared to control group $(\mathrm{p}<0.01) ; * *$ Significant difference compared to chronic cystitis group $(\mathrm{p}<0.01)$.

Table 7. TGF- $\alpha$ expression in malignant cases

\begin{tabular}{|c|c|c|c|c|c|}
\hline \multirow[t]{2}{*}{ Histological diagnosis (n) } & \multirow{2}{*}{$\begin{array}{l}\text { Positive cases } \\
\mathrm{n}(\%)\end{array}$} & \multicolumn{4}{|c|}{ Extent of TGF- $\alpha$ immunoreactivity } \\
\hline & & $\%$ of positive cells (Mean \pm SD) & Score $1+, \mathrm{n}(\%)$ & Score $2+, \mathrm{n}(\%)$ & Score $3+, \mathrm{n}(\%)$ \\
\hline UC (30) & $26(86.7)$ & $42.90 \pm 23.71$ & $3(11.5)$ & $12(46.2)$ & $11(42.3)$ \\
\hline Non-Schistosomal (13) & $10(77)$ & $50.61 \pm 25.78$ & $2(20)$ & $5(50)$ & $3(30)$ \\
\hline $\operatorname{SCC}(15)$ & $15(100)$ & $67.33 \pm 15.79 *$ & 0 & $2(13.3)$ & $13(86.7)$ \\
\hline Non-Schistosomal (5) & $5(100)$ & $68.00 \pm 14.83$ & 0 & $1(20)$ & $4(80)$ \\
\hline Schistosomal (10) & $10(100)$ & $67.00 \pm 17.02$ & 0 & $1(10)$ & $9(90)$ \\
\hline
\end{tabular}

TGF- $\alpha=$ Transforming growth factor alpha; UC = urothelial carcinoma; $\mathrm{SCC}=$ squamous cell carcinoma. *Significant difference compared to UC group $(\mathrm{p}<0.01)$.

TFG alpha immunoexpression

TGF $\alpha$ positive staining was indicated by brown cytoplasmic staining in urothelial cells. Forty percent of control cases showed TGF $\alpha$ immunopositivity ( 2 out of 5 cases), all were in score $1+$, with sequential increase to $70 \%$ in chronic cystitis and $91.2 \%$ in bladder cancer cases. Similarly, the extent of TGF $\alpha$ expression (mean $\%$ of positive cells) increased significantly in bladder cancer over chronic cystitis and control cases $(p<$ $0.01)$. Schistosomal association with cystitis and bladder 


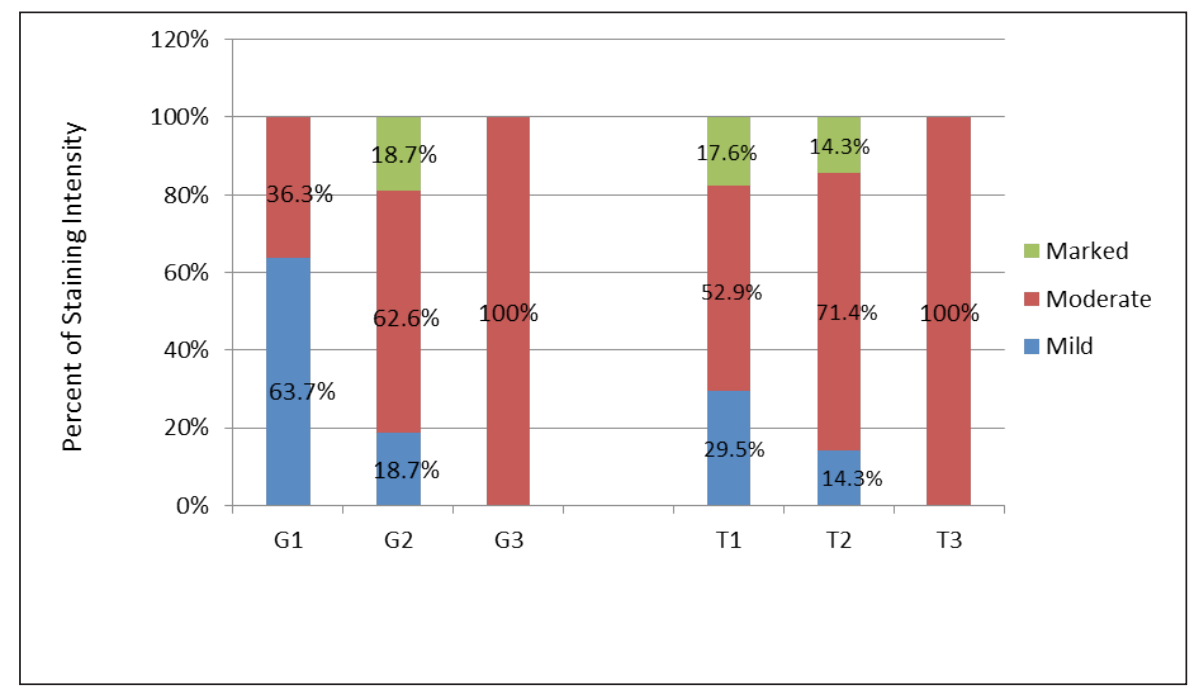

Histogram. 3. Intensity of TGF- $\alpha$ expression in studied groups.

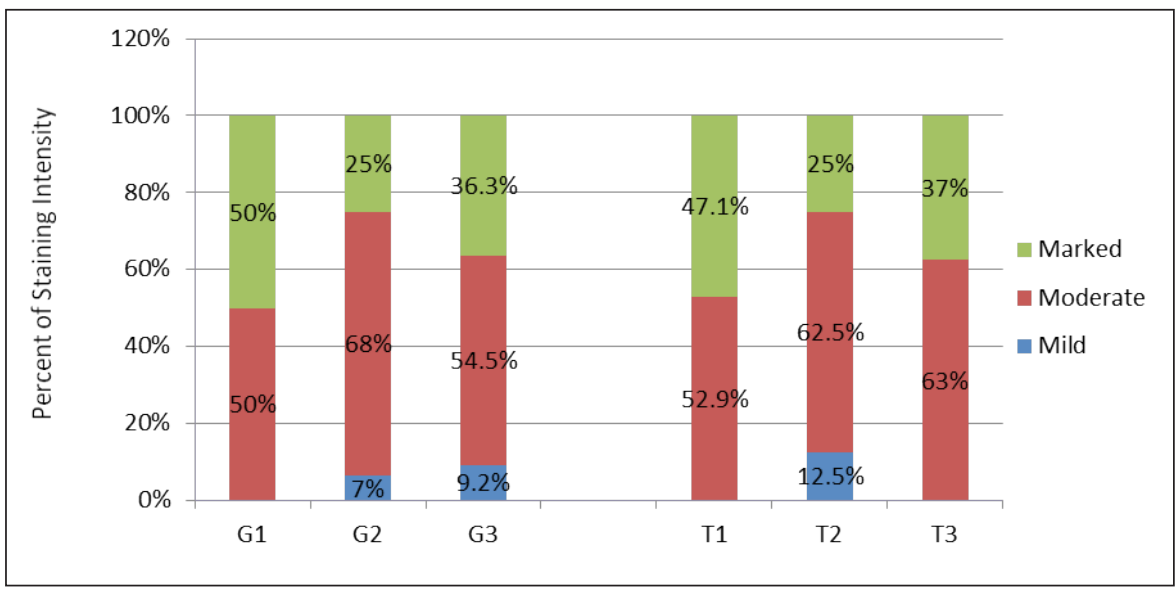

Histogram. 4. Intensity of TGF- $\alpha$ in different grades and stages of positive malignant cases. $\mathrm{G}=$ Grade $; \mathrm{T}=$ Stage.

Table 8. TGF- $\alpha$ expression in malignant grades and stages

\begin{tabular}{|c|c|c|c|c|c|}
\hline \multirow[t]{2}{*}{ Histological diagnosis (n) } & \multirow{2}{*}{$\begin{array}{l}\text { Positive cases } \\
\mathrm{n}(\%)\end{array}$} & \multicolumn{4}{|c|}{ Extent of TGF- $\alpha$ immunoreactivity } \\
\hline & & $\%$ of positive cells $($ Mean \pm SD) & Score $1+, \mathrm{n}(\%)$ & Score $2+, \mathrm{n}(\%)$ & Score $3+, \mathrm{n}(\%)$ \\
\hline \multicolumn{6}{|l|}{ Grade } \\
\hline Grade I (15) & $14(93.3)$ & $50.53 \pm 22.95$ & $3(21.5)$ & $5(35.7)$ & $6(42.8)$ \\
\hline Grade III (12) & $11(91.6)$ & $53.25 \pm 27.49$ & 0 & $2(18.2)$ & $9(81.8)$ \\
\hline \multicolumn{6}{|l|}{ Stage } \\
\hline Stage $1(20)$ & $17(85)$ & $47.40 \pm 26.20$ & $3(17.6)$ & $6(35.3)$ & $8(47)$ \\
\hline
\end{tabular}


cancer increased TGF $\alpha$ positivity, and extent of expression in score 3+ compared to non Schistosomal cases. All positive cases of cystitis either schistosomal or non -schistosomal showed mild staining intensity, while in carcinoma (schistosomal and non-schistosomal) they were mainly of moderate and marked intensity (table 6 and histogram 3).

In SCC TGF $\alpha$ positivity was $100 \%$, while being $86.7 \%$ in UC cases. Extent of TGF $\alpha$ expression (mean \% of positive cells) was significantly higher in SCC than in UC $(\mathrm{p}<0.01)$. In addition schistosomal association increased TGF $\alpha$ positivity and extent of expression in score $3+$ compared to non Schistosomal cases in both SCC and UC (table7 and fig. 2).

No detectable changes in TGF $\alpha$ positivity, or staining intensity among different grades or stages of studied tumors, but extent of expression of score $3+$ increased in higher stages and grades than in lower ones (table 8 and histogram 4).

Spearman's correlation coefficient (r) calculation revealed significant positive correlation between schistosomal association and EGFR positivity $(\mathrm{r}=0.628, \mathrm{p}=$ $0.001)$, EGFR score $(\mathrm{r}=0.619, \mathrm{p}=0.001)$, EGFR staining intensity $(\mathrm{r}=0.279, \mathrm{p}=0.01)$, TGF $\alpha$ positivity $(\mathrm{r}=$ $0.403, \mathrm{p}=0.001), \mathrm{TGF} \alpha$ staining intensity $(\mathrm{r}=0.184, \mathrm{p}=$ $0.01)$, and TGF $\alpha$ score $(r=0.305, p=0.05)$. EGFR score correlated significantly with tumor grade $(\mathrm{r}=0.352, \mathrm{p}=$ $0.01)$ and stage $(r=0.389, p=0.01)$. Also TGF score correlated significantly with tumor grade $(\mathrm{r}=0.312, \mathrm{p}=$ $0.05)$ and stage $(r=0.263, p=0.05)$.

\section{Discussion}

Different studies have established that bladder cancer is the most common cancer in Egypt and most cases were linked with Schistosomiasis [7]. EGFR has been associated with the genesis of bladder tumors [18]. Over-expression of EGFR leads to uncontrolled cell proliferation. It also results in increased angiogenesis and reduced apoptosis, processes necessary for continuing malignant growth [19]. TGF $\alpha$ contributes to transformation and oncogenesis through the activation of EGFR [15].

In our study we detected EGFR immunostaining as membrano-cytoplasmic staining of urothelial cells; this finding is in accordance with results observed by Khaled et al. [13] and Abdulamir et al. [20].

Our 5 control cases were negative for EGFR; this finding is consistent with results of Khaled et al. [13]. Cheng et al. [21] stated that $40-60 \%$ of human bladder tumors

EGFR and TGF $\alpha$ in Bladder Cancer overexpress EGFR mRNA and protein, while Naik et al. [7] reported positive EGFR expression in only $23 \%$ of their malignant cases. In our study $86.7 \%$ of malignant lesions were positive for EGFR; $83 \%$ of non schistosomal and $89 \%$ of schistosomal carcinoma. Abdulamir et al. [20] recorded EGFR overexpresssion in 58\% and 84\% of non schistosomal and schistosomal bladder tumors, and Khaled et al. [13] reported its expression in $66 \%$ of schistosomal bladder cancer.

In current study schistosomal association increased percentage of positive cases for EGFR expression in both cystitis and malignant cases. This finding is consistent with data reported by Abdulamir et al. [20] who concluded that schistosomal cystitis might act as an intermediate stage between normal and tumor tissues indicating the danger of the long-lasting inflammation of the bladder.

For histological types of bladder cancer, EGFR immunopositivity was found in all SCC cases compared to $80 \%$ of UC cases; this is in accordance with Guo et al. [22] and Ibrahim et al. [23] who reported that SCC of the urinary bladder, which is frequently related to schistosomal etiology and an advanced stage, expresses more intensely enhanced levels of EGFR.

Significant association reported in current study between increased EGFR expression with high grade and late stage of cancer bladder is in agreement with Colquhoun et al. [24] and Khaled at al. [13], suggesting that EGFR signaling may play a role in tumor progression [25]. However, Popove et al. [18] demonstrated that EGFR expression had no additional prognostic value over clinical stage, grade or cell proliferation. A study of Memon et al. [26] provided an explanation for this controversial data since they found that in some cases EGFR expression alone shows no correlation with survival, yet a high expression of EGFR together with increased Her3 and Her4 correlate with a better survival, denoting the existence of a synergistic effect between EGFR and other Erb family members mainly Her3/4.

In the current study, TGF $\alpha$ immunoreactivity was detected in $40 \%$ of control cases, this agrees with that reported by Tungekar et al. [27]. TGF $\alpha$ positivity increased to be $70 \%$ in chronic cystitis and $91.2 \%$ in bladder cancer cases matching with data reported by Mellon et al. [28].

Schistosomal association increased the percentage of positive cases for TGF $\alpha$ expression in both cystitis and malignant cases. This finding is consistent with data reported by Swellam et al. [16] who concluded that TGF $\alpha$ appears more frequently in schistosomal bladder cancer 
and SCC, suggesting that it may play an important role in their development. These observations may provide insight into treatment guided by molecular changes.

In our study, TGF $\alpha$ immunopositivity was found in all SCC cases compared to $86.7 \%$ of UC cases; this is in accordance with results reported by Swellam et al. [16] and Tungekar et al. [27].

Swellam et al. [16] found an association between late stages, and high histological grades with $\mathrm{TGF} \alpha$ positivity. In the current work, TGF $\alpha$ also expressed with higher scores in high grades and late tumor stage.
In conclusion, EGFR and TGF $\alpha$ overexpression were found to be more frequent in bladder malignant lesions and stronger in schistosomal versus non-schistosomal cases. EGFR and TGF $\alpha$ overexpression correlated with higher tumor grade and stage, thus can be used as predictors for prognosis.

The current treatment of advanced bladder cancer relies mainly on traditional cytotoxic agents. High expression of biologic markers such as EGFR and TGF $\alpha$ can provide a preclinical proof of concept that anti-EGFR therapy can be used to target bladder tumors expressing these markers.

\section{References}

1 Felix AS, Soliman SA, Khaled H, Zaghloul SM, Banerjee M, El-Baradie M, El-Kalawy M, Abdel-Sayed AA, Ismail K, Hablas A, Seifeldin IA, Ramadan M, Wilson ML: The changing patterns of bladder cancer in Egypt over the past 26 years. Cancer Causes Control 2008;19:421-429.

2 Ploeg M, Aben KK, Kiemeney LA: The present and future burden of urinary bladder cancer in the world. World J Urol 2009;27:289293.

3 Jemal A, Siegel R, Xu J, Ward E: Cancer statistics, 2010. CA Cancer J Clin 2010;60: 277-300.

4 Manunta A, Vincendeau S, Kiriakou G, Lobel B, Guillé F: Non-transitional cell bladder carcinomas. BJU Int 2005;95:497-502.

5 Reuter VE: The urothelial tract: renal pelvis, ureter, urinary bladder, and urethra; in Mills SE, Carter D, Greenson JK, Reuter VE, Stoler MH (eds): Sternberg's Diagnostic Surgical Pathology, ed 5. Philadelphia, Lippincott Williams \& Wilkins, 2010, p1830.

6 el-Mawla NG, eL-Bolkainy MN, Khaled HM: Bladder cancer in Africa: update. Semin Oncol 2001;28:174-181.

7 Naik DS, Sharma S, Ray A, Hedau S: Epidermal growth factor receptor expression in urinary bladder cancer. Indian J Urol 2011; 27:208-214.

8 De Luca A, Carotenuto A, Rachiglio A, Gallo M, Maiello MR, Aldinucci D, Pinto A, Normanno N: The role of the EGFR signaling in tumor microenvironment. J Cell Physiol 2008;214:559-567.
9 Herbst RS: Review of epidermal growth factor receptor biology. Int J Radiat Oncol Biol Phys 2004;59(2 suppl):21-26.

10 Chaux A, Cohen JS, Schultz L, Albadine R, Jadallah R, Murphy KM, Sharma R, Schoenberg MP, Netto GJ: High epidermal growth factor immunohistochemical expression in urothelial carcinoma of the bladder is not associated with EGFR mutations in exons 19 and 21: a study using formalin-fixed, paraffin-embedded archival tissues. Hum Path 2012;43:1590-1595.

11 Cardillo MR, Castagna G, Memeo L, De Bernardinis E, Di Silverio F: Epidermal growth factor receptor, MUC-1 and MUC-2 in bladder cancer. J Exp Clin Cancer Res 2000;19: 225-233.

12 Matsubara H, Yamada Y, Naruse K, Nakamura K, Aoki S, Taki T, Tobiume M, Zennami K, Katsuda R, Honda N: Potential for HER$2 /$ neu molecular targeted therapy for invasive bladder carcinoma: comparative study of immunohistochemistry and fluorescent in situ hybridization. Oncol Rep 2008;19:57-63.

13 Khaled HM, Bahnassy AA, Raafat AA, Zekri AN, Madboul MS, Mokhtar NM: Clinical significance of altered nm23-H1, EGFR, RB and 553 expression in bilharzial bladder cancer. BMC Cancer 2009;9:32

14 Gangarosa LM, Dempsey PJ, Damstrup L, Barnard JA, Coffey RJ: Transforming growth factor-alpha. Baillieres Clin Gastroenterol 1996;10:49-63.
15 Selvaggi G, Novello S, Torri V, Leonardo E, De Giuli P, Borasio P, Mossetti C, Ardissone F, Lausi P, Scagliotti GV: Epidermal growth factor receptor over expression correlates with a poor prognosis in completely resected non-small-cell lung cancer. Ann Oncol 2004; 15:28-32.

16 Swellam M, El-Aal AA, AbuGabel KM: Deletions of p15 and p16 in schistosomal bladder cancer correlate with transforming growth factor-alpha expression. Clin Biochem 2004:37:1098-1104.

17 Eble JN, Sauter G, Epstein JI, Sesterhenn IA: Pathology and genetics of tumours of the urinary system and male genital organs. World Health Organization Classification of Tumors. Lyon, France, International Agency for Research on Cancer (IARC), 2004, pp90157.

18 Popov Z, Gil-Diez-De-Medina S, Ravery V, Hoznek A, Bastuji-Garin S, Lefrere-Belda MA, Abbou CC, Chopin DK: Prognostic value of EGF receptor and tumor cell proliferation in bladder cancer: therapeutic implications. Urol Oncol 2004;22:93-101.

19 Wells A: The epidermal growth factor receptor (EGFR) - a new target in cancer therapy. Signal 2000;1:4-11.

20 Abdulamir AS, Hafidh RR, Kadhim HS, Abubakar F: Tumor markers of bladder cancer: the schistosomal bladder tumors versus non-shistosomal bladder tumors. J Exp Clin Cancer Res 2009;28:27. 
21 Cheng J, Huang H, Zhang ZT, Shapiro E, Pellicer A, Sun TT, Wu XR: Overexpression of epidermal growth factor receptor in urothelium elicits urothelial hyperplasia and promotes bladder tumor growth. Cancer Res 2002;62:4157-4163.

22 Guo CC, Gomez E, Tamboli P, Bondaruk JE, Kamat A, Bassett R, Dinney CP, Czerniak BA: Squamous cell carcinoma of the urinary bladder: a clinicopathologic and immunohistochemical study of 16 cases. Hum Pathol 2009;40:1448-1452
23 Ibrahim N, Elzagheid A, El-Hashmi H, Syrjanen K, Alhakim S: The potential value of EGFR and p53 immunostaining in tumors of the urinary bladder. Libyan J Med 2009;4: 143-145.

24 Colquhoun AJ, Mellon JK: Epidermal growth factor receptor and bladder cancer. Postgrad Med J 2002;78:584-589.

25 Thogersen VB, Jorgensen PE, Sorensen BS, Bross P, Orntoft T, Wolf H, Nexo E: Expression of transforming growth factor and epidermal growth factor receptor in human bladder cancer. Scand J Clin Lab Invest 1999;59: 267-277.
26 Memon AA, Sorensen SB, Nexo E: The epidermal growth factor family has a dual role in deciding the fate of cancer cells. Scand J Clin Lab Invest 2006;66:623-630.

27 Tungekar MF, Linehan J: Patterns of expressions of transforming growth factor and epidermal growth factor receptor in squamous cell lesions of the urinary bladder. J Clin Pathol 1998;51:583-587.

28 Mellon JK, Cook S, Chambers P, Neal DE: Transforming growth factor alpha and epidermal growth factor levels in bladder cancer and their relationship to epidermal growth factor receptor. Br J Cancer 1996;73:654-658. 